\title{
Jin fflemoriam
}

ONCE more the Society has lost by death a valued member, in $\mathrm{Mr}$. Joseph B. Shea, chairman of the board, and former president of the Joseph Horne Company, of Pittsburgh. Mr. Shea attended Princeton, and after his graduation, was engaged in the iron and steel business for a time.

"In a day when steel was the mark of Pittsburgh and Pittsburghers," says an editorial writer in The Pittsburgh Press, "Mr. Shea as a young man turned from the forge to merchandising. He became identified with retail merchandising in I9or, when he became a director of the Joseph Horne Company. His genius in that field became evident, and his progress to the chief executive position at Horne's marched evenly with the expansion of that business house."

Mr. Shea was a director of a number of other corporations, and also for a number of years was a leader in the activities of the Chamber of Commerce. During the World War his organizing ability was sought by the government, and he was chief of an im portant bureau in aircraft production.

Full as his business life was, he found room for numerous other interests. He was a trustee of Princeton University, and lent his coöperation to the civic affairs of his own city. His interest was enlisted by The Business Historical Society, and he became a member of its council. He will be sadly missed by every circle with which he came in contact.

\section{Secretary's Column}

The following acquisitions have been received during the past month and are gratefully acknowledged:

From Walter T. Rosen, New York City, Six valuable seventeenth century pamphlets having to do with trade, particularly with coins, debts and interest. One refers to England and the others to Germany.

From Miss Helen E. Keep, Detroit, Michigan, Nine notebooks containing manuscript of a history of the American stove, prepared by her father, William J. Keep. Also "Cast Iron; a Record of Original Research," by William J. Keep. 